\title{
Perspective
}

\section{HMGB-1 in Psoriasis}

\author{
Marco Casciaro $^{1, * \mathbb{C}}$, Eleonora Di Salvo ${ }^{2}$ and Sebastiano Gangemi $^{1}$
}

1 School and Unit of Allergy and Clinical Immunology, Department of Clinical and Experimental Medicine, University of Messina, 98125 Messina, Italy; gangemis@unime.it

2 Department of Veterinary Sciences, University of Messina, 98168 Messina, Italy; edisalvo@unime.it

* Correspondence: mcasciaro@unime.it or marco.casciaro@unime.it; Tel.: +39-090-2212013

\begin{abstract}
Psoriasis is a multifactorial pathology linked to systemic inflammation. Enhanced keratinocytes proliferation and a minor maturation state of the cells are typical features. Perivascular $\mathrm{T}$ cells, dendritic cells, macrophages, and neutrophilic granulocytes are part of the scenario completed by apoptosis dysregulation. Several proinflammatory mediators, alarmins and growth factors are increased too, both in the skin and the patients' blood. HMGB1 is important as an alarmin in several inflammatory conditions. Released after cellular damage, HMGB1 acts as a danger signal. Several studies have considered its role in psoriasis pathogenesis. We evaluated its level in psoriasis and the potential of the alarmin blockade through standard therapies, biological treatments and using monoclonal antibodies. PV patients were shown to have significantly increased levels of HMGB1 both in lesional skin and in serum, which were linked, in some cases, to other pro-inflammatory markers and alarmins. In most cases these parameters were correlated with PASI score. Data demonstrated that blocking HMGB1 is effective in ameliorating psoriasis. Focusing on this approach could be valuable in terms of a therapeutic option for counteracting immune-related diseases in a way unthinkable until few years ago.
\end{abstract}

Keywords: HMGB-1; psoriasis; alarmin; skin; inflammation; immune system; monoclonal; biologic; therapy

Citation: Casciaro, M.; Di Salvo, E.; Gangemi, S. HMGB-1 in Psoriasis. Biomolecules 2022, 12, 60. https:/ / doi.org/10.3390/biom12010060

\section{Introduction}

Psoriasis is an autoimmune skin disease characterized by a dysregulation of the immune system with multifactorial pathogenesis. The etiology of the disease is still controversial but biochemical, genetic, and environmental factors are fundamental for disease initiation and worsening [1]. This multifactorial pathology is linked to systemic inflammation. Enhanced keratinocytes proliferation and a minor maturation state of these cells is a typical feature [2]. Immune cells infiltration, perivascular $\mathrm{T}$ cells, dendritic cells, macrophages, and neutrophilic granulocytes are part of the scenario, which is completed by apoptotic dysregulation. Several proinflammatory mediators, alarmins and growth factors are also increased too, both in skin and in the patients' blood [3].

\section{Alarmins and Skin}

Interleukin 33 (IL-33) is a molecule discovered in the last decade, which is part of the IL-1 family. It has multiple functions, such as the stimulation of IL-4, IL-5 and IL-13, which are T helper 2 (Th2) cytokines. IL-33 links to the interleukin 1 receptor-like 1 protein (also IL-1RL1 or ST2). Several cells express IL-33. Among these there are fibroblasts, epithelial cells, endothelial cells and activated macrophages. IL-33 has also been recently reported to act also as a danger signal (alarmin) [4]. IL-33 is usually intimately linked to chromatin and is most often represented in cells with a barrier function, (i.e., endothelial and epithelial cells) [5]. A biologically active form of IL-33 is released when these cells are destroyed after damage. For this reason, IL-33 is like other biologically active mediators such as S100 proteins, IL-1 $\beta$ and the high-mobility group box 1 (HMGB1) [6]. 
S100 proteins have intracellular and extracellular functions. Although intracellular capabilities of the molecule have been clearly shown, extracellular functions are still being investigated. S100 proteins are usually released after cell damage. S100A4 and A6 can promote apoptosis, S100B, S100A8/A9, S100A11 and S100A12 inflammation, S100A8 and A9 chemotaxis, and S100P and S100A7 cell proliferation [7]. One molecule important as an alarmin in several inflammatory conditions is HMGB1. It is also called amphoterin, and is a highly conservative damage-associated molecular pattern molecule. It has a dual function. In the nucleus, it regulates nuclear biochemical transactions. Once released after cellular damage, HMGB1 acts as a danger signal resulting from local wounding [8]. HMGB1 has a key role in the human metabolome [9]. As mentioned above there is ever-increasing evidence of its involvement in immunopathology in diverse organs [10,11]. Several studies have considered its role in the pathogenesis of psoriasis, and for this reason we decided to focus on the role of HMGB1 in this skin disease. Particularly, we decided to evaluate the potential of the alarmin blockade using standard therapies, biological treatments and specific monoclonal antibodies.

\section{Materials and Methods}

A review was performed by browsing the PubMed and Scholar databases, searching from inception until 30 October 2021. The search included terms related to psoriasis and high mobility group box-1 (HMGB-1).

We read the abstracts of articles with titles suggesting an association between psoriasis and alarmins. The entire article was read only if the abstract indicated that the article potentially met the inclusion criteria (research article, trials, English-written). Finally, we reviewed and searched the references of these articles to identify further studies which could be included. We included in this perspective a total of 10 research articles.

\section{Results}

Literature data linking psoriasis to HMGB1 alarmin starts in 2013 with Chen et al. Since that first association, other research followed analyzing serum, and lesional skin levels of the alarmin. Researchers observed HMGB1 effects on keratinocytes by using recombinant proteins (Table 1) and some focused on the effects of the HMGB1 blockade (Table 2).

Table 1. HMGB1 serum and tissue concentration and effects in the different types of psoriasis.

\begin{tabular}{|c|c|c|c|c|c|c|}
\hline Alarmin & Author/Year & Tissue & Sample Size & Disease & Effects & Signaling \\
\hline HMGB1 & $\begin{array}{c}\text { Chen } 2017 \\
\text { [12] }\end{array}$ & Skin/blood & Mice model & $\begin{array}{l}\text { Imiquimod- } \\
\text { induced } \\
\text { psoriasis }\end{array}$ & $\begin{array}{l}\text { Worsening of psoriatic } \\
\text { lesions after the } \\
\text { injection of HMGB1 }\end{array}$ & $\begin{array}{c}\text { Enhanced presence of CD3+ } \\
\text { T cells, myeloperoxidase + } \\
\text { neu-trophils and CD11c+ } \\
\text { dendritic cells; } \\
\text { higher number of cd T cells, } \\
\text { and augmented mRNA levels } \\
\text { of IL-6, TNF-a, IFN-c and } \\
\text { IL-17 }\end{array}$ \\
\hline HMGB-1 & $\begin{array}{l}\text { Watanabe } \\
2020[13]\end{array}$ & Skin/blood & 10 patients & $\begin{array}{c}\text { Generalized } \\
\text { pustular } \\
\text { psoriasis (GPP) }\end{array}$ & $\begin{array}{l}\text { Elevated serum } \\
\text { HMGB-1 levels; affected } \\
\text { skin had a high } \\
\text { HMGB-1 expression in } \\
\text { GPP and PV }\end{array}$ & $\begin{array}{c}\text { Correlation between blood } \\
\text { HMGB-1 levels and the } \\
\text { Japanese severity score. } \\
\text { HMGB-1 high levels in the } \\
\text { cytoplasm }\end{array}$ \\
\hline HMGB-1 & $\begin{array}{l}\text { Watanabe } \\
2020[13]\end{array}$ & Skin/blood & 10 patients & $\begin{array}{l}\text { Psoriasis } \\
\text { vulgaris }\end{array}$ & $\begin{array}{l}\text { Serum HMGB-1 levels } \\
\text { increased significantly; } \\
\text { Affected skin had a high } \\
\text { HMGB-1 expression in } \\
\text { GPP and PVHMGB-1 } \\
\text { high levels in the } \\
\text { cytoplasm }\end{array}$ & $\begin{array}{l}\text { HMGB-1 high levels in the } \\
\text { cytoplasm }\end{array}$ \\
\hline HMGB1 & $\begin{array}{c}\text { Borsky } 2020 \\
{[5]}\end{array}$ & Blood & 63 patients & PV & $\begin{array}{c}\text { HMGB1 significantly } \\
\text { elevated. } \\
\text { No significant } \\
\text { correlation with PASI. }\end{array}$ & $\begin{array}{l}\text { Significant correlation } \\
\text { between HMGB1 and } \\
\text { psoriasin }\end{array}$ \\
\hline
\end{tabular}


Table 1. Cont.

\begin{tabular}{|c|c|c|c|c|c|c|}
\hline Alarmin & Author/Year & Tissue & Sample Size & Disease & Effects & Signaling \\
\hline $\begin{array}{l}\text { rHMGB1 } \\
\text { (recombinant } \\
\text { HMGB1) }\end{array}$ & $\begin{array}{c}\text { Wang } 2020 \\
{[14]}\end{array}$ & Intradermal & mice & $\begin{array}{l}\text { psoriasis- } \\
\text { associated } \\
\text { inflammation }\end{array}$ & $\begin{array}{l}\text { Epidermal thickening } \\
\text { and substantial cell } \\
\text { infiltration }\end{array}$ & $\begin{array}{l}\text { Induced Cxcl1, Cxcl2, Ccl20, } \\
\text { S100a7, S100a8, S100a9, and } \\
\text { Defb2 (defensin beta 2) } \\
\text { associated with innate } \\
\text { immunity (Il1b and Tnf), } \\
\text { cytokines in the IL23A-IL17A } \\
\text { axis (Il23a, IL17a, and IL22), } \\
\text { transcription factors } \\
\text { (Rorc/ Ror } \gamma \mathrm{t} \text { ) and the } \\
\text { neutrophil membrane marker } \\
\text { Ly6g }\end{array}$ \\
\hline HMGB1 & $\begin{array}{c}\text { Kamel } 2017 \\
\text { [15] }\end{array}$ & Blood & 50 patients & Psoriasis & $\begin{array}{c}\text { Significantly higher } \\
\text { HMGB1 levels in } \\
\text { patients. } \\
\text { Positive correlation } \\
\text { between PASI score and } \\
\text { serum level of HMGB1 }\end{array}$ & $\begin{array}{l}\text { HMGB1 acts like an } \\
\text { adipocytokine, an innate } \\
\text { proinflammatory mediator. } \\
\text { Higher HMGB1 levels among } \\
\text { psoriatic patients with } \\
\text { metabolic syndrome. }\end{array}$ \\
\hline HMGB1 & $\begin{array}{c}\text { Wang } 2017 \\
\text { [16] }\end{array}$ & Skin & 12 patients & PV & $\begin{array}{l}\text { HMGB1 expression in } \\
\text { epithelial intercellular } \\
\text { spaces increased. } \\
\text { HMGB1 expression in } \\
\text { psoriasis significantly } \\
\text { increased. }\end{array}$ & $\begin{array}{l}\text { HMGB1 diffuse expression in } \\
\text { the nuclei, with low } \\
\text { expression in the cytoplasm of } \\
\text { the squamous epithelium. } \\
\text { Extracellular HMGB1 } \\
\text { occasionallypresent in the } \\
\text { epithelium intercellular } \\
\text { spaces. } \\
\text { In the nuclei and cytoplasm of } \\
\text { associated inflammatory cells } \\
\text { and vascular endothelial cells, } \\
\text { moderate HMGB1 expression. }\end{array}$ \\
\hline rHMGB1 & $\begin{array}{c}\text { Zhang } 2016 \\
\text { [17] }\end{array}$ & Keratinocytes & - & PV & $\begin{array}{l}11 \text { inflammatory factors } \\
\text { (IL18, IL1A, IL6, IL7, } \\
\text { IL24, IL5, CXCL1, } \\
\text { CX3CL1, TNFSF11, } \\
\text { VEGFA) were shown to } \\
\text { be upregulated by } \\
\text { HMGB1 in } \\
\text { keratinocytes, }\end{array}$ & $\begin{array}{l}\text { Interleukin (IL)-18 showed the } \\
\text { greatest change. } \\
\text { The activation of the NfkB } \\
\text { pathway and inflammasomes } \\
\text { accounted for } \\
\text { HMGB1-induced IL-18 } \\
\text { production and release. }\end{array}$ \\
\hline HMGB1 & $\begin{array}{c}\text { Zhang } 2016 \\
\text { [17] }\end{array}$ & Skin & Mice & $\begin{array}{l}\text { Imiquimod- } \\
\text { induced } \\
\text { psoriasis }\end{array}$ & $\begin{array}{c}\text { HMGB1 and } \\
\text { downstream IL-18 } \\
\text { contributed to } \\
\text { psoriasiform dermatitis }\end{array}$ & - \\
\hline HMGB1 & $\begin{array}{c}\text { Bergmann } \\
2016 \text { [18] }\end{array}$ & Blood & $\begin{array}{c}90 \text { psoriatic } \\
\text { patients }\end{array}$ & PV & $\begin{array}{l}\text { HMGB1 levels are } \\
\text { significantly increased } \\
\text { with disease } \\
\text { progression }\end{array}$ & Increased level of HMGB1 \\
\hline HMGB1 & $\begin{array}{l}\text { Strohbuecker } \\
2019 \text { [19] }\end{array}$ & Skin & 22 patients & PV & $\begin{array}{l}\text { Increased staining for } \\
\text { HMGB1 in the dermis } \\
\text { of psoriatic plaques }\end{array}$ & $\begin{array}{l}\text { Histocompatibility complex } \\
\text { class III-encoded DNA and } \\
\text { HMGB1 RAGE, induced by } \\
\text { HMGB1, were highly } \\
\text { expressed on psoriatic CD8+ } \\
\text { T cells and CD4+ Treg. } \\
\text { High RAGE levels, on the cell } \\
\text { surface of keratino- cytes. }\end{array}$ \\
\hline HMGB1 & $\begin{array}{c}\text { Chen } 2013 \\
\text { [20] }\end{array}$ & Blood/skin & 51 patients & PV & $\begin{array}{l}\text { HMGB1 significantly } \\
\text { higher; it correlated } \\
\text { with PV severity and } \\
\text { PASI score. }\end{array}$ & $\begin{array}{l}\text { HMGB1 in normal skin was } \\
\text { mostly limited to the nucleus. } \\
\text { High cytoplasmic expression } \\
\text { of HMGB1 in the epidermis in } \\
\text { lesional skin of PV patients. }\end{array}$ \\
\hline
\end{tabular}


Table 2. Effects of HMGB1 neutralizing by experimental approaches or conventional therapies in psoriasis.

\begin{tabular}{|c|c|c|c|c|c|c|}
\hline Alarmin & Author/Year & Tissue & Sample Size & Disease & Effects & Signaling \\
\hline $\begin{array}{l}\text { Anti-HMGB1 } \\
\text { (anti-HMGB1 } \\
\text { monoclonal } \\
\text { antibody or } \\
\text { HMGB1 inhibitor } \\
\text { glycyrrhizin) }\end{array}$ & Chen 2017 [12] & Skin/blood & Mice model & $\begin{array}{l}\text { Imiquimod- } \\
\text { induced } \\
\text { psoriasis }\end{array}$ & $\begin{array}{l}\text { Mild clinical and } \\
\text { tissue evolvement }\end{array}$ & $\begin{array}{l}\text { It reduced the number } \\
\text { of cd T cells, } \\
\text { suppressed the } \\
\text { mRNA expression of } \\
\text { IL-6, TNF-a, IFN-c } \\
\text { and IL-17 }\end{array}$ \\
\hline $\begin{array}{l}\text { TNF-a inhibitors } \\
\text { and one with granu- } \\
\text { locytapheresis } \\
\text { (against HMGB1) }\end{array}$ & $\begin{array}{c}\text { Watanabe } 2020 \\
\text { [13] }\end{array}$ & Skin/blood & 7 patients & GPP & $\begin{array}{c}\text { Clinical } \\
\text { improvement } \\
\text { (GPP severity } \\
\text { score, } 0 \text { or } 1 \text { ) after } \\
\text { systemic } \\
\text { treatment. }\end{array}$ & $\begin{array}{l}\text { HMGB-1 significantly } \\
\text { reduced after } \\
\text { systemic treatment. } \\
\text { Positive correlation } \\
\text { between HMGB-1 and } \\
\text { the GPP severity score }\end{array}$ \\
\hline $\begin{array}{c}\text { Injection of } \\
\text { lentivirus } \\
\text { expressing a small } \\
\text { hairpin RNA } \\
\text { (shRNA) against } \\
\text { Hmgb1 (Hmgb1 } \\
\text { shRNA) }\end{array}$ & Wang 2020 [14] & Subcutis & mice & $\begin{array}{l}\text { Imiquimod- } \\
\text { induced } \\
\text { psoriasis }\end{array}$ & $\begin{array}{c}\text { Epidermal } \\
\text { thickening and } \\
\text { inflammation }\end{array}$ & $\begin{array}{l}\text { Deregulation of } \\
\text { psoriasis-related } \\
\text { genes }\end{array}$ \\
\hline $\begin{array}{c}\text { HMGB1- } \\
\text { neutralizing } \\
\text { antibodies }\end{array}$ & Zhang 2016 [17] & $\begin{array}{l}\text { Peritoneally } \\
\text { injected }\end{array}$ & Mice & $\begin{array}{l}\text { Imiquimod- } \\
\text { induced } \\
\text { psoriasis }\end{array}$ & $\begin{array}{c}\text { Thinner } \\
\text { epidermis than } \\
\text { controls }\end{array}$ & $\begin{array}{l}\text { T-helper } 17 \text { immune } \\
\text { response inhibited by } \\
\text { both HMGB1 and } \\
\text { IL-18 blockade }\end{array}$ \\
\hline $\begin{array}{l}\text { TNF } \alpha \text {-inhibitors, } \\
\text { fumaric acid esters } \\
\text { and methotrexate }\end{array}$ & $\underset{\text { [18] }}{\text { Bergmann }} 2016$ & Blood & $\begin{array}{l}90 \text { psoriatic } \\
\text { patients }\end{array}$ & PV & $\begin{array}{l}\text { HMGB1 was } \\
\text { reduced during } \\
\text { therapy }\end{array}$ & $\begin{array}{c}\text { TGF- } \beta 1 \text { and IL-23 } \\
\text { were decreased }\end{array}$ \\
\hline
\end{tabular}

\section{1. $H M G B-1$}

Chen et al. reported for the first time that circulating levels of HMGB1 in PV patients were higher than in healthy subjects. Blood HMGB1 was correlated with PV severity according to PASI scores. High cytoplasmic HMGB1 levels in PV lesional skin were also reported. Immunohistochemistry and immunofluorescence demonstrated the presence of HMGB1 only in the nucleus of normal skin. HMGB1 was expressed in the nucleus of healthy subjects but not in the cytoplasm [20].

Imiquimod (IMQ) induced psoriasis-like inflammation was exposed to recombinant HMGB1 and to phosphate-buffered saline (PBS) i.d. Lesional skin from IMQ-treated mice presented high cytoplasmic levels of HMGB1 and the administration of HMGB1 into the lesional skin further worsened the psoriasis-like disease. As a result, HMGB1 augmented the infiltration of CD3+ T cells, myeloperoxidase + neutrophils and CD11c+ dendritic cells, increased the number of cd T cells, and upregulated the mRNA expression of interleukin (IL)-6, tumor necrosis factor (TNF)-a, interferon (IFN)-c and IL-17 [12].

Watanabe et al. studied the expression of HMGB-1 in generalized pustular psoriasis (GPP). An increase in HMGB-1 expression was significantly higher in GPP patients [13]. Borsky et al. found significantly increased levels of HMGB1 but focused on PV. They found a positive relationship between HMGB1 and S100A7 [5].

Wang et al. injected wild-type (WT) mice intradermally with recombinant HMGB1 (rHMGB1). The mice tested underwent epidermal thickening and cell infiltration. rHMGB1 triggered inflammatory mediators associated with PV, such as: Cxcl1, Cxcl2, and Ccl20, S100a7, S100a8, S100a9, and Defb2 (defensin beta 2), IL1b and TNF, IL23A-IL17A axis cytokines IL23a, IL17a, and IL22, transcription factors (Rorc/Ror $\gamma \mathrm{t}$ ) and the neutrophil membrane marker Ly6g [21].

Kamel et al. evaluated serum HMGB1 in PV and correlated it with disease severity. Moreover, they compared the levels in PV patients with and without metabolic syndrome. They realized that HMGB1 was higher in patients than in controls, and was correlated with disease activity. Metabolic syndrome was associated with high levels of the alarmin [15]. 
Wang et al. observed a positive HMGB1 representation in the nucleus of lesional skin; whereas they reported a weak positive presence in the cytoplasm of the squamous epithelium. Extracellular HMGB1 was only rarely present in the epithelium intercellular spaces. They also found that the nucleus and cytoplasm of associated inflammatory cells and vascular endothelial cells were mildly positive to HMGB1. However, HMGB1 levels in epithelial intercellular spaces in psoriasis were increased more than in controls [16].

Zhang et al. investigated if HMGB1 had proinflammatory effects on keratinocytes and how could it contribute to PV development. Human keratinocytes were tested with recombinant human HMGB1. The authors evaluated the variation of inflammatory factors and intermediary signaling pathways. Several inflammatory factors (a total of 11) were triggered and upregulated by HMGB1 in keratinocytes. Interleukin (IL)-18 showed the most significant elevation. The activation of the nuclear factor-B pathway and inflammasomes were connected to the production and release of IL-18 induced by HMGB1. Moreover, the imiquimod-induced psoriasis mice model was used to check the role of HMGB1 in PV equilibrium in vivo. HMGB1, and subsequently IL-18, determined the development of psoriasiform dermatitis in the imiquimod-treated mouse model [17].

Bergmann et al. demonstrated that extracellular serum HMGB1 level affected by severe PV was higher than in healthy controls. They showed that the increase was linked to disease progression [18].

Strohbuecker et al. observed high positive staining for HMGB1 in the cutis of psoriatic lesions compared to the healthy skin of PV patients. Moreover, both the major histocompatibility complex class III-encoded DNA and HMGB1 RAGE, endorsed by HMGB1, were abundantly represented on psoriatic CD8+ T cells and CD4+ Treg. High expression of HMGB1 and RAGE were reported on severe PV plaques [19].

\subsection{Alarmin Blockade}

Chen et al., using an anti-HMGB1 monoclonal antibody and the HMGB1 inhibitor glycyrrhizin, reported that HMGB1 blockade resulted in a diminished number of cd $\mathrm{T}$ cells. Another result was the suppression of IL-6, TNF-a, IFN-c and IL-17 mRNA. This scenario was reflected by a mild clinical and histological progression in the IMQ-treated skin [12]. Watanabe et al. reported that serum HMGB-1 levels were significantly decreased after systemic treatment with TNF-a inhibitors or with granulocytapheresis. The authors reported a high positive correlation between serum HMGB-1 levels and the Japanese severity score for GPP [13]. Wang et al. generated Hmgb1-KD animals by the subcutaneous administration of a lentivirus expressing a small hairpin RNA (shRNA) versus Hmgb1 (Hmgb1 shRNA). IMQ induced psoriasis-like inflammation was significantly reduced in KD mice compared to WT mice. Clinical parameters, such as PASI, were sustained by mice epidermal thickening and inflammation, and downregulation of psoriasis-related genes. Blocking extracellular HMGB1 led to comparable results. It was speculated that T-helper 17 immune response in the IMQ model could be blocked by both HMGB1 and IL-18 inhibition by the administration of neutralizing antibodies. This treatment resulted in a much thinner epidermis than in controls [14]. According to Bergamnn et al., patients who underwent methotrexate administration showed the lowest circulating levels of HMGB1. Patients treated with TNF $\alpha$-inhibitors or fumaric acid esters also had reduced levels of circulating HMGB1. Among the treatments evaluated, only IL-12/IL-23 inhibitors did not influence blood HMGB1 [18]. Another experiment focused on the injection of HMGB1neutralizing antibodies in psoriatic mice peritoneum. The authors reported a diminished number of infiltrating CD3+ T cells and CD4+ ROR $\gamma t+$ Th17 cells in skin lesions and reduced circulating levels of IL-17. According to their results, HMGB1 sustained the Th17 immune response in PV via caspase 1 cleavage and, in turn, the release of IL-18 from keratinocytes [17]. 


\section{Discussion}

The alarmin, HMGB1, as a nuclear binding molecule is intimately connected with chromatin. It is secreted from several immune cells or accidentally released from cells after permanent damage, acting as a proinflammatory cytokine. It exerts its inflammatory activity by interacting with multiple receptors such as the receptor for advanced glycation end products (RAGE), the Toll-like receptor (TLR) 2 and TLR 4. The alarmin, in turn, stimulates the release of other proinflammatory mediators such as TNF $\alpha$ and IL-1 $\beta$, resulting in cell damage which, releases more HMGB1 in an autocrine loop. As explained below, the redox status of HMGB1 has main role in immunological activity during damage-associated secretion. However, a unique trigger of PV is undetectable. HMGB1, which is secreted by keratinocytes and immune cells after certain damage or situations, plays a main role in PV immunopathogenesis by influencing phagocytosis and the differentiation of regulatory $\mathrm{T}$ cells into IL-17-producing cells [18].

HMGB1 could function as a proinflammatory cytokine; as a result, it contributes to the development of psoriasis-like inflammation [12]. The presence of this alarmin influences the balance of chronic inflammation in psoriasis with a particular involvement of Treg and Th17cells [20]. HMGB1 plays its role in several autoimmune diseases such as encephalomyelitis, thyroiditis, myocarditis, systemic lupus erythematosus and many others [22-25]. The alarmin is involved in this specific case in PV because of its release by keratinocytes and diverse immune cells, such as activated macrophages, mature dendritic cells, and natural killer cells after damage, infection, or other kinds of triggers. It acts as a main character in PV by interfering with homeostasis, by compromising the normal immunosuppressive phenotype and enhancing inflammation. The link between HMGB1 and its receptors stimulates RAGE expression, inducing a Th17 shift in subjects affected by psoriasis and, in turn, sustaining the inflammatory condition (Figure 1). Borsky et al. found an interesting correlation between HMGB1 and psoriasin. This relationship was judged as a signal of their simultaneous release during the psoriatic autoimmune process. Moreover, they could be released after the death of specific cells [5]. HMGB1 released from skin, in particular from keratinocytes, may endorse the recruitment of inflammatory factors on site such as IL-18, replicating an autocrine loop in keratinocytes. The loop described could promote the onset of psoriasis [17]. Further results endorsed the endocrine alarmin pro-inflammatory hypothesis. A clue was the link between PV and metabolic syndrome and HMGB1 high levels in obese patients [26]. For this reason, some researchers proposed that HMGB1 could act as an adipocytokine, mimicking an innate proinflammatory molecule in patients with a high BMI. These findings were supported by HMGB1 correlation with other inflammatory markers of metabolic syndrome [27]. Therefore, the hypothesis that psoriasis is worsened by high levels of the alarmin is supported by the data reported above, suggesting an interesting therapeutic application.

\subsection{Clinical Application as a Therapeutic Target}

Borsky et al. focused on other interesting alarmins to support HMGB1 results. They found significantly increased levels of IL-33 in PV patients and reported a consistent link between HMGB1 and IL-33 in healthy controls [5]. S100A7 was increased and they observed a relationship with HMGB1. The same result was obtained for S100A12. According to their results, targeting these molecules is of importance to contain inflammation. For example, anti-IL-33 monoclonal antibodies have provided promising results in other skin conditions linked to inflammation, such as atopic dermatitis (AD). A phase 2 a trial with etokimab, a humanized IgG1/ kappa anti-IL-33 monoclonal antibody, was performed with 12 moderateto-severe adult AD patients. Etokimab was given at an SD of $300 \mathrm{mg}$ intravenously. Twelve patients were observed for 140 days. All 12 patients achieved at least EASI-50 after an SD of etokimab, and three patients achieved IGA 0/1. Data reported endorse etokimab as an effective biologic in $\mathrm{AD}$, although it is at an initial investigational stage [28]. Monoclonal antibodies demonstrated their potential on several other inflammatory conditions [14,29]. For this reason, the HMGB1 blockade may represent a new direction in the suppression of 
psoriasis [12]. Blocking the proinflammatory function of the HMGB1-IL-18 axis may be useful for psoriasis treatment in the future [17]. More data may encourage researchers to evaluate a trial in animals and, in the near future, in patients affected by psoriasis.

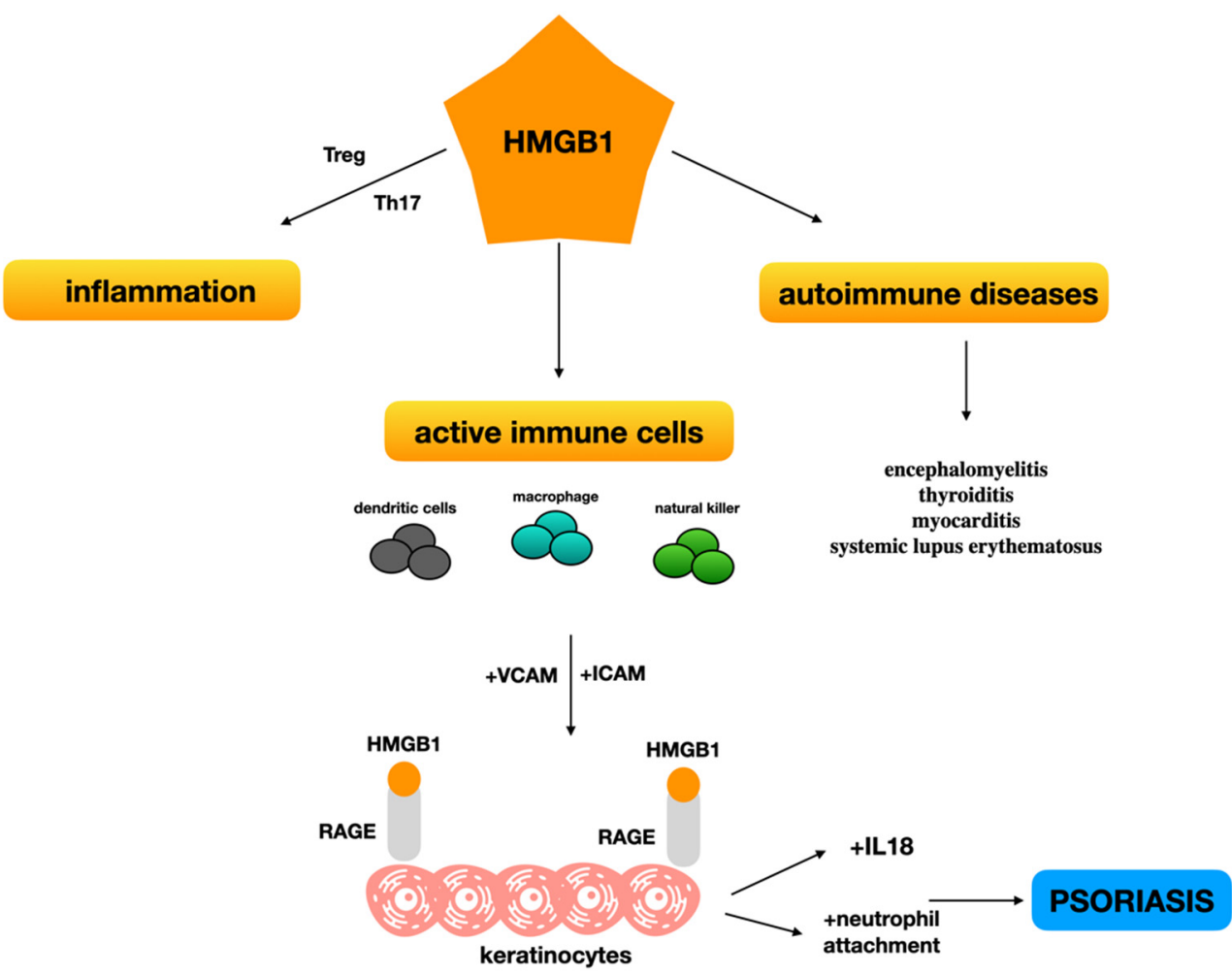

Figure 1. HMGB-1 involvement in the inflammatory process endorsing psoriasis plaque formation.

\subsection{Role of Oxidative Stress}

Alarmins, and in particular HMGB1, are released after cellular damage [9]. For this reason they have a major role in the chronic inflammatory loop in several diseases [30]. In this scenario, oxidative stress is intimately linked to cell damage and immune recruitment. Psoriasis is no exception [2]. The epidermis is a particularly sensitive tissue to free radicals. Once exposed to ROS, there is an accumulation of oxidation products which recruit immune system cells such as monocytes, macrophages, and neutrophils. The pro-inflammatory mediators released cause damage and stimulate production of other ROS, which lead to molecular alterations and to a re-amplification of the inflammatory response [2]. In this detrimental loop, alarmins act as catalysts, released after cell destruction. Controlling HMGB1, together with following an antioxidant healthy lifestyle, including a diet rich in antioxidants and nutraceutical intake, could greatly ameliorate PASI score and patient life quality $[2,31]$.

\section{Conclusions}

PV patients had significantly increased levels of HMGB1 in lesional skin and serum. In some cases, this was linked to other pro-inflammatory markers and alarmins such as IL-33, S100A7, and S100A12. In most cases these parameters were correlated to PASI score. The discovery of the relationship between HMGB1, psoriasis and chronic inflammation is arousing much interest. First, alarmins could be useful as diagnostic biomarkers and monitoring substances for treatments. Second, initial data have demonstrated that blocking HMGB1 is effective in ameliorating psoriasis similar to blocking some other alarmins (e.g., IL-33) in other chronic inflammatory skin diseases (e.g., atopic dermatitis). Focusing on this approach could be valuable in terms of therapeutic options for counteracting immune related diseases in a way unthinkable until few years ago. 


\begin{abstract}
Author Contributions: Conceptualization, S.G. and M.C.; methodology, E.D.S.; formal analysis, E.D.S.; investigation, E.D.S.; resources, S.G.; data curation, S.G., M.C. and E.D.S.; writing-original draft preparation, M.C. and E.D.S.; writing—review and editing, M.C. and S.G.; visualization, E.D.S.; supervision, S.G.; project administration, S.G. All authors have read and agreed to the published version of the manuscript.
\end{abstract}

Funding: This research received no external funding.

Institutional Review Board Statement: Not applicable.

Informed Consent Statement: Not applicable.

Data Availability Statement: Not applicable.

Conflicts of Interest: The authors declare no conflict of interest. Marco Casciaro is a member of the topic editors' panel.

\title{
References
}

1. Griffiths, C.E.; Barker, J.N. Pathogenesis and Clinical Features of Psoriasis. Lancet 2007, 370, 263-271. [CrossRef]

2. Cannavò, S.; Riso, G.; Casciaro, M.; Di Salvo, E.; Gangemi, S. Oxidative Stress Involvement in Psoriasis: A Systematic Review. Free Radic. Res. 2019, 53, 829-840. [CrossRef]

3. Das, D.; Akhtar, S.; Kurra, S.; Gupta, S.; Sharma, A. Emerging Role of Immune Cell Network in Autoimmune Skin Disorders: An Update on Pemphigus, Vitiligo and Psoriasis. Cytokine Growth Factor Rev. 2019, 45, 35-44. [CrossRef]

4. Haraldsen, G.; Balogh, J.; Pollheimer, J.; Sponheim, J.; Küchler, A.M. Interleukin-33—Cytokine of Dual Function or Novel Alarmin? Trends Immunol. 2009, 30, 227-233. [CrossRef] [PubMed]

5. $\quad$ Borsky, P.; Fiala, Z.; Andrys, C.; Beranek, M.; Hamakova, K.; Malkova, A.; Svadlakova, T.; Krejsek, J.; Palicka, V.; Borska, L.; et al. Alarmins HMGB1, IL-33, S100A7, and S100A12 in Psoriasis Vulgaris. Mediat. Inflamm. 2020, 2020, e8465083. [CrossRef] [PubMed]

6. Di Salvo, E.; Ventura-Spagnolo, E.; Casciaro, M.; Navarra, M.; Gangemi, S. IL-33/IL-31 Axis: A Potential Inflammatory Pathway. Mediat. Inflamm. 2018, 2018, 3858032. [CrossRef] [PubMed]

7. Donato, R.; Cannon, B.R.; Sorci, G.; Riuzzi, F.; Hsu, K.; Weber, D.J.; Geczy, C.L. Functions of S100 Proteins. Curr. Mol. Med. 2013, 13, 24-57. [CrossRef]

8. Andersson, U.; Erlandsson-Harris, H.; Yang, H.; Tracey, K.J. HMGB1 as a DNA-Binding Cytokine. J. Leukoc. Biol. 2002, 72, 1084-1091. [CrossRef]

9. Bertheloot, D.; Latz, E. HMGB1, IL-1 $\alpha$, IL-33 and S100 Proteins: Dual-Function Alarmins. Cell. Mol. Immunol. 2017, 14, 43-64. [CrossRef]

10. Imbalzano, E.; Quartuccio, S.; Di Salvo, E.; Crea, T.; Casciaro, M.; Gangemi, S. Association between HMGB1 and Asthma: A Literature Review. Clin. Mol. Allergy 2017, 15, 12. [CrossRef]

11. Gangemi, S.; Casciaro, M.; Trapani, G.; Quartuccio, S.; Navarra, M.; Pioggia, G.; Imbalzano, E. Association between HMGB1 and COPD: A Systematic Review. Mediat. Inflamm. 2015, 2015, 164913. [CrossRef]

12. Chen, T.; Fu, L.; Guo, Z.; Yin, B.; Cao, N.; Qin, S. Involvement of High Mobility Group Box-1 in Imiquimod-Induced Psoriasis-like Mice Model. J. Dermatol. 2017, 44, 573-581. [CrossRef]

13. Watanabe, T.; Yamaguchi, Y.; Watanabe, Y.; Takamura, N.; Aihara, M. Increased Level of High Mobility Group Box 1 in the Serum and Skin in Patients with Generalized Pustular Psoriasis. J. Derm. 2020, 47, 1033-1036. [CrossRef]

14. Wang, J.; Fu, L.; Yang, H.; Cao, K.; Sun, Q.; Chen, T. The Anti-Inflammatory Effects of HMGB1 Blockades in a Mouse Model of Cutaneous Vasculitis. Front. Immunol. 2020, 11, 2032. [CrossRef] [PubMed]

15. Kamel Role of High-Mobility Group Box-1 as a Marker of Disease Severity and Diagnosis of Metabolic Syndrome in Psoriatic Patients. Available online: https: / / www.ejdv.eg.net/article.asp?issn=1110-6530;year=2017; volume=37;issue=2; ;page=69;epage= 75 ; aulast=Kamel (accessed on 13 October 2021).

16. Wang, Y.; Weng, H.; Song, J.F.; Deng, Y.H.; Li, S.; Liu, H.B. Activation of the HMGB1-TLR4-NF-kB Pathway May Occur in Patients with Atopic Eczema. Mol. Med. Rep. 2017, 16, 2714-2720. [CrossRef] [PubMed]

17. Zhang, W.; Guo, S.; Li, B.; Liu, L.; Ge, R.; Cao, T.; Wang, H.; Gao, T.; Wang, G.; Li, C. Proinflammatory Effect of High-Mobility Group Protein B1 on Keratinocytes: An Autocrine Mechanism Underlying Psoriasis Development. J. Pathol. 2017, 241, 392-404. [CrossRef] [PubMed]

18. Bergmann, C.; Strohbuecker, L.; Lotfi, R.; Sucker, A.; Joosten, I.; Koenen, H.; Körber, A. High Mobility Group Box 1 Is Increased in the Sera of Psoriatic Patients with Disease Progression. J. Eur. Acad. Derm. Venereol. 2016, 30, 435-441. [CrossRef] [PubMed]

19. Strohbuecker, L.; Koenen, H.; van Rijssen, E.; van Cranenbroek, B.; Fasse, E.; Joosten, I.; Körber, A.; Bergmann, C. Increased Dermal Expression of Chromatin-Associated Protein HMGB1 and Concomitant T-Cell Expression of the DNA RAGE in Patients with Psoriasis Vulgaris. Psoriasis 2019, 9, 7-17. [CrossRef]

20. Chen, T.; Guo, Z.; Li, L.; Wang, L.; Jia, R.; Cao, N.; Qin, S.; Li, M. Increased HMGB1 Serum Levels and Altered HMGB1 Expression in Patients with Psoriasis Vulgaris. Arch. Derm. Res. 2013, 305, 263-267. [CrossRef] 
21. Wang, Z.; Zhou, H.; Zheng, H.; Zhou, X.; Shen, G.; Teng, X.; Liu, X.; Zhang, J.; Wei, X.; Hu, Z.; et al. Autophagy-Based Unconventional Secretion of HMGB1 by Keratinocytes Plays a Pivotal Role in Psoriatic Skin Inflammation. Autophagy 2021, 17, 529-552. [CrossRef]

22. Robinson, A.P.; Caldis, M.W.; Harp, C.T.; Goings, G.E.; Miller, S.D. High-Mobility Group Box 1 Protein (HMGB1) Neutralization Ameliorates Experimental Autoimmune Encephalomyelitis. J. Autoimmun. 2013, 43, 32-43. [CrossRef]

23. Li, C.; Peng, S.; Liu, X.; Han, C.; Wang, X.; Jin, T.; Liu, S.; Wang, W.; Xie, X.; He, X.; et al. Glycyrrhizin, a Direct HMGB1 Antagonist, Ameliorates Inflammatory Infiltration in a Model of Autoimmune Thyroiditis via Inhibition of TLR2-HMGB1 Signaling. Thyroid 2017, 27, 722-731. [CrossRef]

24. Su, Z.; Zhang, P.; Yu, Y.; Lu, H.; Liu, Y.; Ni, P.; Su, X.; Wang, D.; Liu, Y.; Wang, J.; et al. HMGB1 Facilitated Macrophage Reprogramming towards a Proinflammatory M1-like Phenotype in Experimental Autoimmune Myocarditis Development. Sci. Rep. 2016, 6, 21884. [CrossRef]

25. Abdulahad, D.A.; Westra, J.; Limburg, P.C.; Kallenberg, C.G.M.; Bijl, M. HMGB1 in Systemic Lupus Erythematosus: Its Role in Cutaneous Lesions Development. Autoimmun. Rev. 2010, 9, 661-665. [CrossRef]

26. Zhang, J.; Zhang, L.; Zhang, S.; Yu, Q.; Xiong, F.; Huang, K.; Wang, C.-Y.; Yang, P. HMGB1, an Innate Alarmin, Plays a Critical Role in Chronic Inflammation of Adipose Tissue in Obesity. Mol. Cell. Endocrinol. 2017, 454, 103-111. [CrossRef] [PubMed]

27. Shimizu, T.; Yamakuchi, M.; Biswas, K.K.; Aryal, B.; Yamada, S.; Hashiguchi, T.; Maruyama, I. HMGB1 Is Secreted by 3T3-L1 Adipocytes through JNK Signaling and the Secretion Is Partially Inhibited by Adiponectin. Obesity 2016, 24, 1913-1921. [CrossRef] [PubMed]

28. Chen, Y.-L.; Gutowska-Owsiak, D.; Hardman, C.S.; Westmoreland, M.; MacKenzie, T.; Cifuentes, L.; Waithe, D.; Lloyd-Lavery, A.; Marquette, A.; Londei, M.; et al. Proof-of-Concept Clinical Trial of Etokimab Shows a Key Role for IL-33 in Atopic Dermatitis Pathogenesis. Sci. Transl. Med. 2019, 11, eaax2945. [CrossRef] [PubMed]

29. Schierbeck, H.; Lundbäck, P.; Palmblad, K.; Klevenvall, L.; Erlandsson-Harris, H.; Andersson, U.; Ottosson, L. Monoclonal Anti-HMGB1 (High Mobility Group Box Chromosomal Protein 1) Antibody Protection in Two Experimental Arthritis Models. Mol. Med. 2011, 17, 1039-1044. [CrossRef] [PubMed]

30. Yang, D.; Han, Z.; Oppenheim, J.J. Alarmins and Immunity. Immunol. Rev. 2017, 280, 41-56. [CrossRef] [PubMed]

31. Mannucci, C.; Casciaro, M.; Sorbara, E.E.; Calapai, F.; Di Salvo, E.; Pioggia, G.; Navarra, M.; Calapai, G.; Gangemi, S. Nutraceuticals against Oxidative Stress in Autoimmune Disorders. Antioxidants 2021, 10, 261. [CrossRef] 